\title{
等方性 $\mathrm{Ba}-\mathrm{Zn}-\mathrm{Al}-\mathrm{La}$ 系 $\mathrm{W}$ 型六方晶フェライト 磁石の磁気特性*
}

Hiroshi Yamamoto, Mitsuru Nagakura, Hideaki Ono and Yoshiaki Takahashi: Magnetic Properties of Isotropic Ba-Zn-Al-La System W-type Hexagonal Ferrite Magnets.

Experiments were carried out to investigate the effects of $\mathrm{Al}_{2} \mathrm{O}_{3}$ and $\mathrm{La}_{2} \mathrm{O}_{3}$ substitution on magnetic properties of isotropic $\mathrm{BaO} \cdot 2 \mathrm{ZnO} \cdot 8 \mathrm{Fe}_{2} \mathrm{O}_{3}$ magnets. The compositions were chosen according to the formula $\left\{(\mathrm{BaO})_{0.091}(\mathrm{ZnO})_{0.183}\left(\mathrm{Fe}_{2} \mathrm{O}_{3}\right)_{0.727}\right\}_{100-\mathrm{X}-\mathrm{Y}}\left(\mathrm{Al}_{2} \mathrm{O}_{3}\right)_{\mathrm{X}}\left(\mathrm{La}_{2} \mathrm{O}_{3}\right)_{\mathrm{Y}}$ where $\mathrm{X}$ was varied between 0 and 5 , and $\mathrm{Y}$ between 0 and 4 . The raw materials used in this experiment were $\alpha-\mathrm{Fe}_{2} \mathrm{O}_{3}, \mathrm{BaCO}_{3}, \mathrm{ZnO}_{2} \mathrm{Al}_{2} \mathrm{O}_{3}$ and $\mathrm{La}_{2} \mathrm{O}_{3}$ powders. Mixed powders of the raw materials prepared by the wet-mixing method were semisintered at $1200 \sim 1400^{\circ} \mathrm{C}$ in air for $1 \mathrm{~h}$. The resulting products were finely ground by a vibration-mill crusher, compacted into cylindrical specimens, and then sintered at $1225 \sim 1350^{\circ} \mathrm{C}$ in air for $0.5 \mathrm{~h}$. The magnetic properties of $\left\{(\mathrm{BaO})_{0.091}(\mathrm{ZnO})_{0.182}\left(\mathrm{Fe}_{2} \mathrm{O}_{3}\right)_{0.727}\right\}_{100-\mathrm{X}-\mathrm{Y}}\left(\mathrm{Al}_{2} \mathrm{O}_{3}\right)_{\mathrm{X}}\left(\mathrm{La}_{2} \mathrm{O}_{3}\right)_{Y}$ magnets were apparently improved by the substitution of $\mathrm{Al}_{2} \mathrm{O}_{3}$ and $\mathrm{La}_{2} \mathrm{O}_{3}$ for $\mathrm{BaO} \cdot 2 \mathrm{ZnO} \cdot 8 \mathrm{Fe}_{2} \mathrm{O}_{3}$ compound. Some properties of a typical specimen are as follows. The preparation condition: composition $\left\{(\mathrm{BaO})_{0.091}\right.$ $(\mathrm{ZnO})_{0.182}\left(\mathrm{Fe}_{2} \mathrm{O}_{3}\right)_{0.727}{ }_{94}\left(\mathrm{Al}_{2} \mathrm{O}_{3}\right)_{4}\left(\mathrm{La}_{2} \mathrm{O}_{3}\right)_{2}$, semisintering condition $1300^{\circ} \mathrm{C} \times 1 \mathrm{~h}$ in air, sintering condition $1300^{\circ} \mathrm{C} \times 0.5 \mathrm{~h}$ in air. Magnetic and physical properties: $\mathrm{J}_{\mathrm{m}}=0.373 \mathrm{~T}, \mathrm{~J}_{\mathrm{r}}=0.250 \mathrm{~T}, \mathrm{H}_{\mathrm{CJ}}=104.8 \mathrm{kA} / \mathrm{m}$, $\mathrm{H}_{\mathrm{CB}}=90.4 \mathrm{kA} / \mathrm{m},(\mathrm{BH})_{\max }=8.42 \mathrm{~kJ} / \mathrm{m}^{3}, \mathrm{~T}_{\mathrm{C}}=346^{\circ} \mathrm{C}, \mathrm{D}=4.68 \mathrm{Mg} / \mathrm{m}^{3}, \mathrm{a}=5.883 \times 10^{-10} \mathrm{~m}, \mathrm{c}=32.84 \times 10^{-10}$ $\mathrm{m}, \mathrm{c} / \mathrm{a}=5.582$.

(Received December 10, 1986)

\section{I 緒言}

W型フェライト磁石は，1980年オランダ・フィリップ ス社の F. K. Lotgering 等 によって, $\mathrm{BaO} \cdot 2 \mathrm{FeO} \cdot 8$ $\mathrm{Fe}_{2} \mathrm{O}_{3}$ 化合物が，現在工業化されている $\mathrm{M}$ 型フェライ トと比べて飽和磁束密度が約 $10 \%$ 高く，異方性磁界がほ 浔同じであるという発表がなされ，優れた異方性磁石材 料として注目を浴びている。しかし，その製造工程は複 䧴な雾囲気と温度の制御が必要であり, 現在のところエ 業化は難しいとされている。一方，W型フェライトの研 究としては，W型フェライトの二洒の鉄イオンを $\mathrm{Mg}$, $\mathrm{Zn}+\mathrm{Mn}, \mathrm{Zn}+\mathrm{Cu}, \mathrm{Zn}+\mathrm{Cd}, \mathrm{Zn}+\mathrm{Mg}^{2 \sim 6)}$ 等によって, また三価の鉄イオンを $\mathrm{Sc}, \mathrm{Al}, \mathrm{Ga}, \mathrm{In}^{7 \sim 10\rangle}$ 等によって置 換した化合物について発表されているが，磁石特性につ いてはきわ的て少なく，わずか纪異方性磁石の ${ }^{11,12}$ 報告 がされているにすきない。

本実験は，W型フェライト磁石の製造方法を確立し， 等方性磁石としての磁気的性質を明らかにすることを 目的に, $\mathrm{BaO} \cdot 2 \mathrm{ZnO} \cdot 8 \mathrm{Fe}_{2} \mathrm{O}_{3} \mathrm{~W}$ 型フェライトの一部を $\mathrm{Al}_{2} \mathrm{O}_{3}$ 及び $\mathrm{La}_{2} \mathrm{O}_{3}$ にて置換した化合物について, 組成,
仮焼成条件，本燒成条件等が磁石の磁気的，物理的特性 にいかなる影響を与えるかについて，詳細䎲実験検討し た。

\section{口実 験 方 法 13,14 )}

実験に用いた原材料は, $\mathrm{BaCO}_{3}, \mathrm{ZnO}, \alpha-\mathrm{Fe}_{2} \mathrm{O}_{3}, \mathrm{Al}_{2} \mathrm{O}_{3}$, $\mathrm{La}_{2} \mathrm{O}_{3}$ 粉末である. これら粉末の化学分析值を Table 1 に示す。組成は, $\left\{(\mathrm{BaO})_{0.091}\left(\mathrm{ZnO}_{0.182}\left(\mathrm{Fe}_{2} \mathrm{O}_{3}\right)_{0.727}\right\}_{100-\mathrm{X}-\mathrm{Y}}\right.$ $\left(\mathrm{Al}_{2} \mathrm{O}_{3}\right)_{\mathrm{X}}\left(\mathrm{La}_{2} \mathrm{O}_{3}\right)_{\mathrm{Y}}$ の組成式において, $\mathrm{X}=0 \sim 5, \mathrm{Y}=0 \sim 4$ まで変化させたものである.

科量は上記組成になるように原材料を用いて総量 0.3 $\mathrm{kg}$ になるように行い，混合はボールミル（湿式法）で

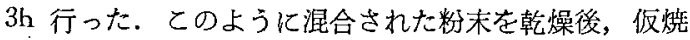

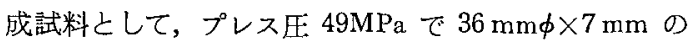
円柱状に成型した。 とれら成型した試料をテコランダム 管状炉を用いて，大気中で $1200 \sim 1400^{\circ} \mathrm{C}$ の温度範囲

* 昭和 61 年本協会春季大会にて一部発表，昭和 61 年 12 月 10 日 受理.

** 明治大学工学部電気工学科, ₹214 川崎市多摩区東三田1-1 -1 . 
Table 1 Chemical composition of raw materials.

\begin{tabular}{c|c}
\multicolumn{2}{c}{$\mathrm{BaCO}_{3}(\mathrm{wt} \%)$} \\
\hline $\mathrm{BaCO}_{3}$ & 99.0 \\
\hline $\mathrm{Cl}$ & 0.001 \\
$\mathrm{Na}$ & 0.005 \\
$\mathrm{~Pb}$ & 0.001 \\
$\mathrm{Fe}$ & 0.001 \\
$\mathrm{~S}$ & 0.001 \\
\hline
\end{tabular}

\begin{tabular}{l|l}
\multicolumn{2}{c}{$\mathrm{Al}_{2} \mathrm{O}_{3}$} \\
\hline $\mathrm{Al}_{2} \mathrm{O}_{3}$ & 98.8 \\
\hline $\mathrm{SO}$ & 0.05 \\
$\mathrm{Cl}$ & 0.001 \\
$\mathrm{SO}_{4}$ & 0.05 \\
$\mathrm{NH}_{4}$ & 0.05 \\
$\mathrm{Fe}$ & 0.0005 \\
$\mathrm{~Pb}$ & 0.0005 \\
\hline
\end{tabular}

\begin{tabular}{l|l}
\multicolumn{2}{c}{$\mathrm{ZnO}(\mathrm{wt} \%)$} \\
\hline $\mathrm{ZnO}$ & 99.3 \\
\hline $\mathrm{Cl}$ & 0.0005 \\
$\mathrm{SO}_{4}$ & 0.006 \\
$\mathrm{PO}_{4}$ & 0.0005 \\
$\mathrm{~Pb}$ & 0.003 \\
$\mathrm{Fe}$ & 0.0005 \\
$\mathrm{Mn}$ & 0.0005 \\
\hline
\end{tabular}

\begin{tabular}{l|c}
\multicolumn{2}{c}{$\mathrm{La}_{2} \mathrm{O}_{3}(w t \%)$} \\
\hline $\mathrm{La}_{2} \mathrm{O}_{3}$ & 99.9 \\
\hline \multicolumn{2}{c}{$\mathrm{Fe}_{2} \mathrm{O}_{3}(w t \%)$} \\
\hline $\mathrm{Fe}_{2} \mathrm{O}_{3}$ & 99.33 \\
\hline $\mathrm{SiO}_{2}$ & 0.03 \\
$\mathrm{SO}_{4}$ & 0.19 \\
$\mathrm{MnO}_{2}$ & 0.34 \\
$\mathrm{H}_{2} \mathrm{O}$ & 0.18 \\
$\mathrm{Cl}$ & 0.05 \\
\hline
\end{tabular}

で $1 \mathrm{~h}$ 仮焼成を行った．引き続き，仮焼成された試料片 を鉄乳鉢を用いて 100 メッシュ以下に破碎した後，ステ ンレス製振動ミル（湿式法）を用いて $8 \mathrm{~h}$ 粉砕した。 と れら粉碎後の粉末の平均粒径は，空気透過法により測定

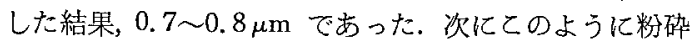
された泾状仮焼成粉末をプレス圧 $294 \mathrm{MPa}$ で, $13 \mathrm{~mm}$ $\times 11 \sim 13 \mathrm{~mm}$ の円柱状に成形した. 本焼成は大気中で, $1225 \sim 1350^{\circ} \mathrm{C}$ の温度範囲で $0.5 \mathrm{~h}$ 焼成した。

試料の諸特性は, 磁石特性については高感度自記磁束 計,キュリー温度はVV.S.M.で測定した。 また, 密度 は水中法で, 組織はS.E.M.を用いて観察し, 結晶構造 はX線粉末法によって検討した。

\section{III 実験結果並びに考察}

3-1 $\left\{(\mathrm{BaO})_{0.091}(\mathrm{ZnO})_{0.182}\left(\mathrm{Fe}_{2} \mathrm{O}_{3}\right)_{0.727}\right\}_{100-\mathrm{x}}\left(\mathrm{Al}_{2} \mathrm{O}_{3}\right)_{\mathrm{X}} \quad$ 化 合物磁石の諸特性

\section{3-1-1 磁気特性}

Fig. 1 は, 基本組成である $\mathrm{BaO} \cdot 2 \mathrm{ZnO} \cdot 8 \mathrm{Fe}_{2} \mathrm{O}_{3}$ 化合 物 $(\mathrm{X}=0$ 組成)におりる本焼成温度之磁気特性の関係 を示したものである.なお，乙の時の仮焼成温度は， $1250 \sim 1350^{\circ} \mathrm{C}$ まで変化させた. 図中の $\mathrm{J}_{\mathrm{m}}$ 洛測定印加磁 界を $800 \mathrm{kA} / \mathrm{m}$ としたときの磁束密度である，また $\mathrm{S}$. C. は本焼成条件，S.S.C. は仮焼成条件を表している. 図から知られるように， $J_{\mathrm{m}}$ と $J_{\mathrm{r}}$ は，いずれの仮燒成温

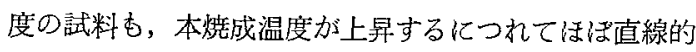
に増加する傾向を示している， $\mathrm{H}_{\mathrm{CJ}}, \mathrm{H}_{\mathrm{CB}}$ は，一般の粉 末冶金の磁石に兒られるように，本焼成温度とともに減 少することが知られたが，これらの值はM型フェライト に比べて小さく，40〜 $75 \mathrm{kA} / \mathrm{m}$ 程度である. $(\mathrm{BH})_{\max }$ は,

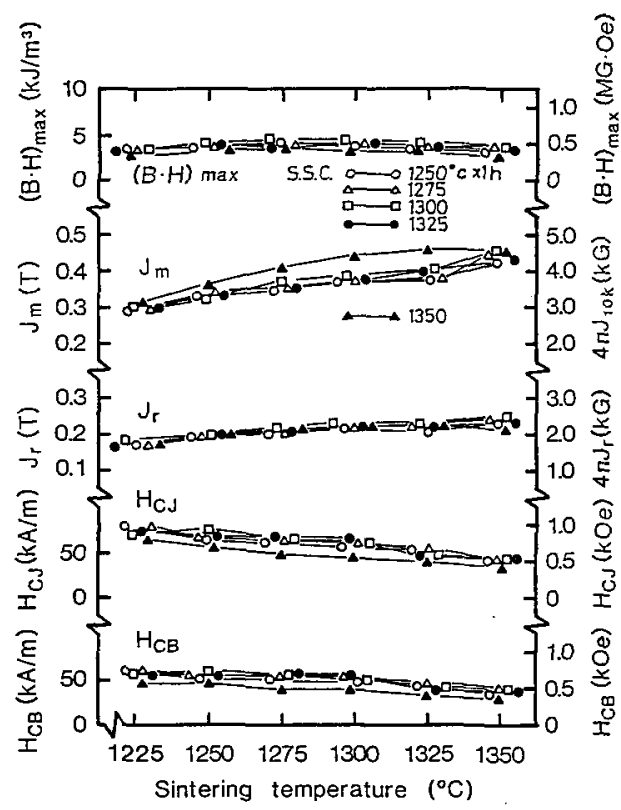

Fig. 1 Effect of sintering temperature on magnetic properties of $\mathrm{BaO} \cdot 2 \mathrm{ZnO} \cdot 8 \mathrm{Fe}_{2} \mathrm{O}_{3}$ compound at various semisintering temperatures.

本焼成温度に柈う変化は見られなく, $5.0 \mathrm{~kJ} / \mathrm{m}^{3}$ 程度が 得られた。

一方，仮狫成温度の影響については，仮狫成温度 1250 $\sim 1325^{\circ} \mathrm{C}$ の場合には大きな变化は見られない.しかし， 仮焼成温度 $1350^{\circ} \mathrm{C}$ の斌料は， $\mathrm{J}_{\mathrm{r}}$ については他の仮烓成

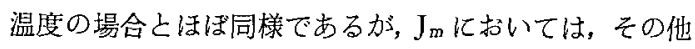
の仮焼成温度の試料より $0.03 \sim 0.07 \mathrm{~T}$ 大きな值である ことが知られる. $\mathrm{H}_{\mathrm{CJ}}$ と $\mathrm{H}_{\mathrm{CB}}$ に扣いては, 反対に 1250〜 $1325^{\circ} \mathrm{C}$ の仮焼成温度の試料に比へて, 仮焼成温度 $1350^{\circ} \mathrm{C}$ の㪶は小さな值を取ることが知られた。したがって， (BH) $\max$ は保磁力の低下のためにいずれの本焼成温度 に括いてむ，仮焼成温度 $1350^{\circ} \mathrm{C}$ の試料は，最李小さな 値を示している，以上のように，乙の系の仮焼成温度 は，1250〜 $1300^{\circ} \mathrm{C}$ と高いが，M型等方性フェライト磁 石では, 900 $1000^{\circ} \mathrm{C}$ の仮哇成温度の場合に良好な磁石 特性を示すととが知られている. そこで, $\mathrm{BaO} \cdot 2 \mathrm{ZnO}$. $8 \mathrm{Fe}_{2} \mathrm{O}_{3}$ 組成 $\mathrm{W}$ 型フェライト磁石においても仮燒成温度 を $1000^{\circ} \mathrm{C}$ として試料を作成したが，本焼成温度 1250 $1300^{\circ} \mathrm{C}$ において $\mathrm{H}_{\mathrm{CJ}}$ は 5 14 kA/m 程度であり, Fig. 1 に示す仮燒成温度の試料より磁石特性は極端に小さいと とが知られた．このように，等方性W型フェライト磁石 は, 等方性 $M$ 型フェライト磁石より, 高い仮焼成温度で 作製する必要があると思われる。

この系で, 最高の磁気特性は, 仮狫成温度 $1300^{\circ} \mathrm{C}$, 本 燒成温度 $1275^{\circ} \mathrm{C}$ で作製された試料で, $\mathrm{J}_{\mathrm{m}}=0.370 \mathrm{~T}, \mathrm{~J}_{\mathrm{r}}$ $=0.220 \mathrm{~T}, \mathrm{H}_{\mathrm{CJ}}=65.2 \mathrm{kA} / \mathrm{m}, \mathrm{H}_{\mathrm{CB}}=56.0 \mathrm{kA} / \mathrm{m},(\mathrm{BH})_{\max }$ 


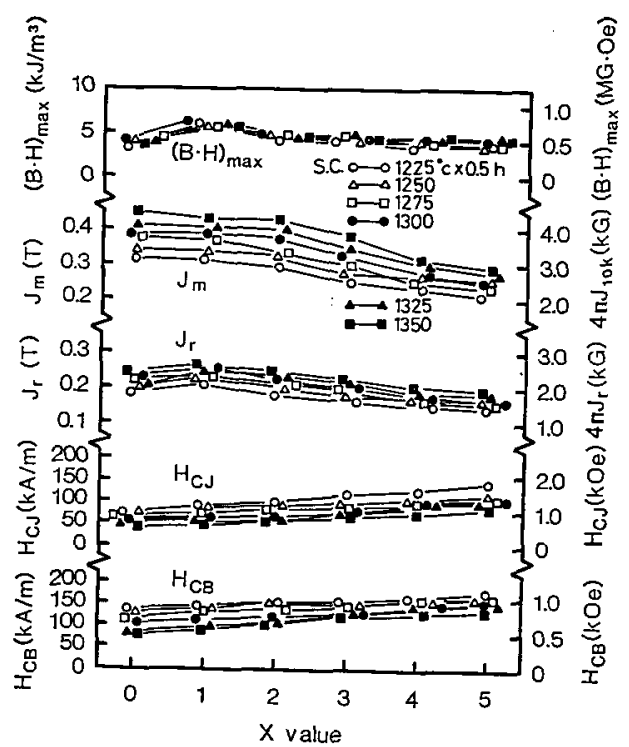

Fig. 2 Effect of $\mathrm{X}$ value on magnetic properties of $\left\{(\mathrm{BaO}\}_{0.091}(\mathrm{ZnO})_{0.182}\left(\mathrm{Fe}_{2} \mathrm{O}_{3}\right)_{0.727}\right\}_{100}-\mathrm{X}\left(\mathrm{Al}_{2} \mathrm{O}_{3}\right)_{\mathrm{X}}$ compounds at various sintering temperatures.

$=5.00 \mathrm{~kJ} / \mathrm{m}^{3}$ が得られたが, 保磁力が低いために $(\mathrm{BH})_{\text {max }}$ 恃従来の $\mathrm{M}$ 型等方性磁石には及ばない。

$\mathrm{BaO} \cdot 2 \mathrm{ZnO} \cdot 8 \mathrm{Fe}_{2} \mathrm{O}_{3}$ 化合物では，前述のように大きな 保磁力が得られなかったので，乙机ら化合物の一部を $\mathrm{Al}_{2} \mathrm{O}_{3}$ で㯰換するととによって, 磁気特性の向上を目的 に実験検討した。

Fig. 2 は, $\left\{(\mathrm{BaO})_{0.091}(\mathrm{ZnO})_{0.182}\left(\mathrm{Fe}_{2} \mathrm{O}_{3}\right)_{0.727}\right\}_{100-\mathrm{x}}\left(\mathrm{Al}_{2}\right.$ $\left.\mathrm{O}_{3}\right) \mathrm{X}$ 化合物に招いて，X=0〜5 と变化させたときの組 成之磁気特性の関係を示したあのである．乙の時の仮焼 成条件は $1300^{\circ} \mathrm{C} \times 1 \mathrm{~h}$ である. 図から知られるように， $\mathrm{J}_{\mathrm{m}}$ はXの増加に伴って減少を示しており, 特に $\mathrm{X}=2$ 〜 5 の範国では $\mathrm{X}=0$ ２ の範囲よりもやや大きな減少を 示している. $\mathrm{J}_{\mathrm{r}}$ に関しては, $\mathrm{X}=0$ ～1 に扔いて約 $10 \%$ 前 後の上昇を示し，その後は $\mathrm{X}$ の增加ととむに直線的な 減少をすることが知られた。このような $\mathrm{J}_{\mathrm{m}}$ の $\mathrm{X}$ の増加 に伴う減少はM型フェライトに扔いても報告(15)されてい るように，磁気モーメントを持たない $\mathrm{Al}^{+++}$が結晶内 においてスピン方向が上向きの $\mathrm{Fe}^{+++}$位置に置換して いるためであると考えられる. しかし，X=1において $\mathrm{J}_{\mathrm{r}}$ が上㫧する理由については，琴在のととろ不明であ る。また， $\mathrm{H}_{\mathrm{CJ}}, \mathrm{H}_{\mathrm{CB}}$ は，いずれの本烧成温度の場合に おいてす，ほぼ直線的な上昇を示している。(BH) $)_{\max }$ は， $\mathrm{J}_{\mathrm{r}}$ と同じように $\mathrm{X}=0$ 0 1 で上昇し, その後は X の増加 に伴って減少あるいはほぼ一定の傾向を示すととが知ら れた。これらの結果加ら, $\mathrm{Al}_{2} \mathrm{O}_{3}$ 置換の影響については， $\mathrm{Al}_{2} \mathrm{O}_{3}$ の少量置換 $(\mathrm{X}=1)$ 亿よって, $\mathrm{J}_{\mathrm{r}}$ が上昇し, その ため磁気特性は $\mathrm{X}=1$ で改善され，本烧成温度 $1300^{\circ} \mathrm{C}$

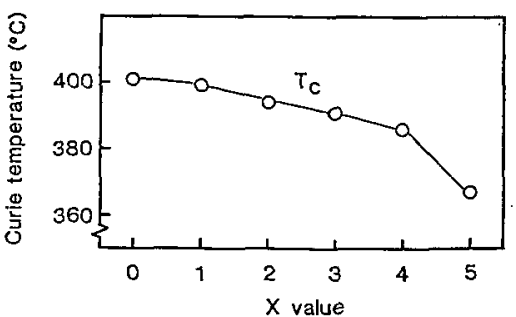

Fig. 3 Curie temperature of $\left\{(\mathrm{BaO})_{0.091}(\mathrm{ZnO})_{0.182}\right.$ $\left.\left(\mathrm{Fe}_{2} \mathrm{O}_{3}\right)_{0.727}\right\}_{100-x}\left(\mathrm{Al}_{2} \mathrm{O}_{3}\right) \times$ compounds. S.S.C.: $1300^{\circ} \mathrm{C} \times 1 \mathrm{~h}$, S.C.: $1300^{\circ} \mathrm{C} \times 0.5 \mathrm{~h}$

において $6.18 \mathrm{~kJ} / \mathrm{m}^{3}$ が得られた。 さらに $\mathrm{X}=2 \sim 5$ の範 囲においては保磁力は增加することが知られたが， J $\mathrm{m}$, J⿸は減少するため磁気特性は向上しないととが知られた。

Fig. 3 は, $\left\{(\mathrm{BaO})_{0.091}(\mathrm{ZnO})_{0.182}\left(\mathrm{Fe}_{2} \mathrm{O}_{3}\right)_{0.727}\right\}_{100-\mathrm{x}}\left(\mathrm{Al}_{2}\right.$ $\left.\mathrm{O}_{3}\right) \times$ 化合物において，X=0〜5 と変化させたときのキ ユリ一温度を示したものである. 図加ら知られるように， $\mathrm{T}_{\mathrm{C}}$ は, $\mathrm{X}=0 \sim 4$ の組成でほぼ直線的に娍少し, $\mathrm{X}=5$ 組 成では大きな減少を示すととが認められた。このととは

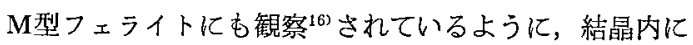

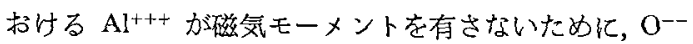
イオンを介しての磁気的相互作用が弱められ， $\mathrm{T}_{\mathrm{C}}$ の減少 が起こるあの之考えられる.なお，磁気特性の问上が認 められた $\mathrm{X}=1$ の組成では $\mathrm{T}_{\mathrm{C}}=400^{\circ} \mathrm{C}$ であった。

\section{3-1-2 X線回折，格子定数}

Fig. 4 は, $\left\{(\mathrm{BaO})_{0.091}(\mathrm{ZnO})_{0.182}\left(\mathrm{Fe}_{2} \mathrm{O}_{3}\right)_{0.727}\right\}_{100-\mathrm{X}}\left(\mathrm{Al}_{2}\right.$ $\left.\mathrm{O}_{3}\right) \mathrm{X}$ 化合物仁おいて, $\mathrm{X}=0 \sim 5$ と変化させた場合の $\mathrm{X}$ 線回折図形である。乙れらは $1300^{\circ} \mathrm{C}$ にて仮焼成し, $1300^{\circ} \mathrm{C}$ で本瑨成した化合物粉末である。なお，図の最

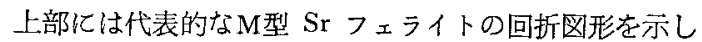
てある. 図から分かるように, X=0〜5 の全ての組成に おいてW相単相か確認され，Ba-Zn 系化合物への $\mathrm{Al}_{2} \mathrm{O}_{3}$ の固溶が確認された。

Fig. 5 は, Fig. 4 と同様の化合物に扰ける組成と格子 定数 (a 及び c) の関係を示したものである.とれはゴニ オメーターの $2 \theta$ を $I^{\circ}$ 当り 4 分で回転させて得られた $\mathrm{X}$ 線回折図形から算出した．図より格子定数 $\mathrm{a}, \mathrm{c}$ いずれも $\mathrm{X}$ の增加に従って減少する傾向認められたが, c/a は $\mathrm{X}$ の值に無関係にほぼ一定を示した．とのような結果 は, $\mathrm{Al}^{+++}$が $\mathrm{Fe}^{+++}$上りあ小さなイオン半径を有し固溶 するこよから得られたもの之考えられる．また， $\mathrm{X}=0$ の組成では $\mathrm{a}=5.890 \times 10^{-10} \mathrm{~m}, \mathrm{c}=32.91 \times 10^{-10} \mathrm{~m}, \mathrm{X}=1$ の組成では $\mathrm{a}=5.889 \times 10^{-10} \mathrm{~m}, \mathrm{c}=32.89 \times 10^{-10} \mathrm{~m}$ の值が 得られた。

3-2 $\left\{(\mathrm{BaO})_{0.091}(\mathrm{ZnO})_{0.182}\left(\mathrm{Fe}_{2} \mathrm{O}_{3}\right)_{0.727}\right\}_{100-\mathrm{X}-\mathrm{Y}}\left(\mathrm{Al}_{2} \mathrm{O}_{3}\right)_{\mathrm{X}}$ $\left(\mathrm{La}_{2} \mathrm{O}_{3}\right)_{\mathrm{Y}}$ 化合物磁石の諸特性

\section{3-2-1 磁気特性}

前述のようK $\mathrm{Ba}-\mathrm{Zn}$ 系化合物を $\mathrm{Al}_{2} \mathrm{O}_{3}$ で置換するこ 


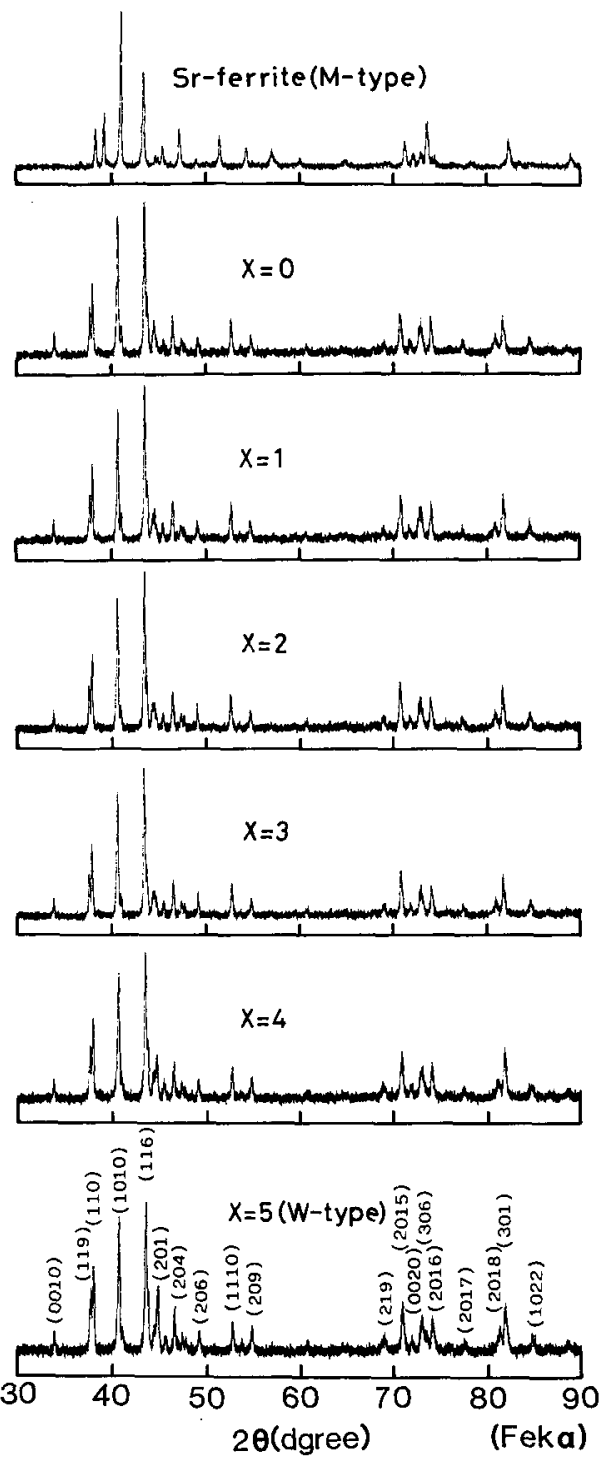

Fig. 4 X-ray diffraction patterns of $\left\{(\mathrm{BaO})_{0.091}(\mathrm{ZnO})_{0.182}\right.$ $\left.\left(\mathrm{Fe}_{2} \mathrm{O}_{3}\right)_{0.72}\right\}_{100-\mathrm{X}}\left(\mathrm{Al}_{2} \mathrm{O}_{3}\right)_{\mathrm{X}} \mathrm{compounds.}$

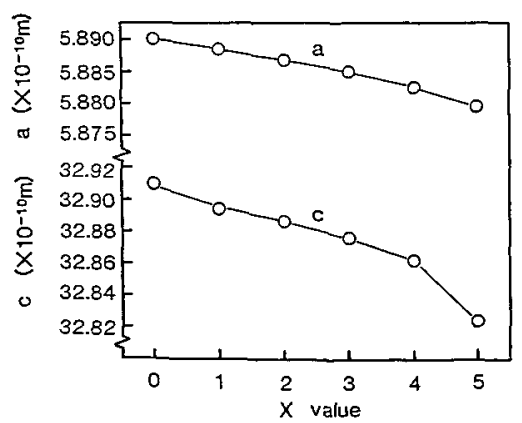

Fig. 5 Lattice constant of $\left\{(\mathrm{BaO}\}_{0.091}(\mathrm{ZnO})_{0.182}\right.$ $\left.\left(\mathrm{Fe}_{2} \mathrm{O}_{3}\right)_{0.727}\right\}_{100-\mathrm{X}}\left(\mathrm{Al}_{2} \mathrm{O}_{3}\right)_{\mathrm{X}}$ compounds. S.S.C.: $1300^{\circ} \mathrm{C} \times 1$ h, S.C.: $1300^{\circ} \mathrm{C} \times 0.5 \mathrm{~h}$
とにより保磁力が増加するととが知られたが，とてでは 著者等が従来のM型フェライトの一部を $\mathrm{La}_{2} \mathrm{O}_{3}{ }^{13}$.14) 㯰 換した結果を考え，W型フェライトにあその影響につい て丰験検討した。

$\mathrm{Ba}-\mathrm{Zn}-\mathrm{Al}$ 系化合物における $\mathrm{La}_{2} \mathrm{O}_{3}$ 置換の影響につ いては，上記組成で， $\mathrm{X}=0 \sim 5$ においてそれぞれ $\mathrm{Y}=0$ 〜4 まで変化させて実験検討を行ったが，ここでは最高 の磁気特性が得られた $\mathrm{X}=4$ の系列について以下に述べ る.

Fig. 6 は, $\left\{(\mathrm{BaO})_{0.091}(\mathrm{ZnO})_{0.182}\left(\mathrm{Fe}_{2} \mathrm{O}_{3}\right)_{0.727}\right\}_{96-\mathrm{Y}}\left(\mathrm{Al}_{2}\right.$ $\left.\mathrm{O}_{3}\right)_{4}\left(\mathrm{La}_{2} \mathrm{O}_{3}\right)_{\mathrm{Y}}$ 化合物において, Y を0 4まで变化ざせた ときの磁気特性を示している，この上き，仮焟成温度は $1300^{\circ} \mathrm{C}$ とし, 本燒成温度は $1225 \sim 1350^{\circ} \mathrm{C}$ まで変化させ た。図汃ら知られるように， $J_{m}$ 及び $J_{r}$ は $\mathrm{Y}=0$ 〜 おいて急激な上昇を示し, 本焼成温度によって傾问は若 干異なるが, $\mathrm{Y}=1$ 又は $\mathrm{Y}=2$ によって最大值を取り， その後は Y の増加に伴いほぼ一定屯しくは，わずかに

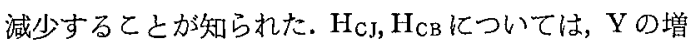
加に対して上昇する傾向が認められ，特に $\mathrm{H}_{\mathrm{CJ}}$ におい て, 本燒成温度が $1225 \sim 1300^{\circ} \mathrm{C}$ と低い場合にとの傾问 は顕著に現れることが知られた。 $(\mathrm{BH})_{\max }$ は，本㶹成温 度が $1300^{\circ} \mathrm{C}$ の試料を除いて Y の増加に伴って上昇を示 し， $\mathrm{Y}=2$ において最大值を取り，その後は $\mathrm{Y}$ としに ほぼ一定又はわずかな减少を示すことが知られた。

このように, $\mathrm{Ba}-\mathrm{Zn}-\mathrm{Al}$ 系化合物に $\mathrm{La}_{2} \mathrm{O}_{3}$ 置換するこ とによって $\mathrm{J}_{\mathrm{m}}$ が上昇する現象は，W相結晶内に招りる各 金属イオンの配置に関連するすのと思われる. Table 2

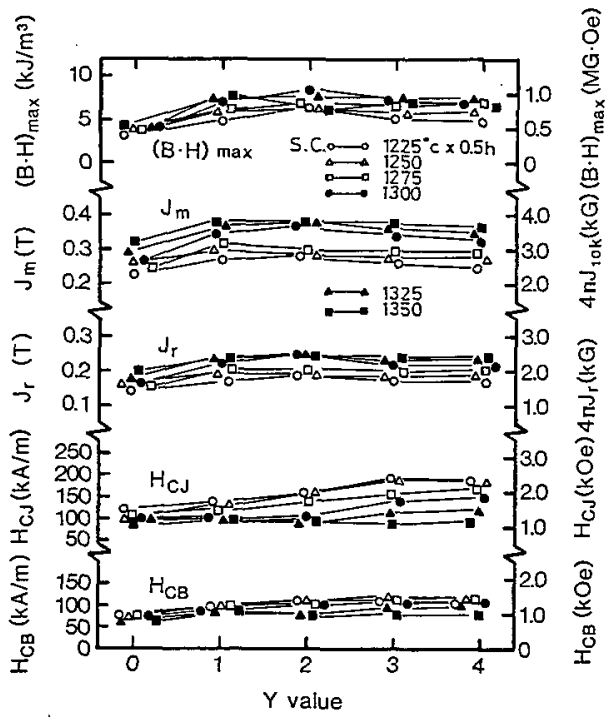

Fig. 6 Effect of $\mathrm{Y}$ value on magnetic properties of $\left\{(\mathrm{BaO})_{0.091}(\mathrm{ZnO})_{0.182}\left(\mathrm{Fe}_{2} \mathrm{O}_{3}\right)_{0.727}\right\}_{96-\mathrm{Y}}$ $\left(\mathrm{Ai}_{2} \mathrm{O}_{3}\right)_{4}\left(\mathrm{La}_{2} \mathrm{O}_{3}\right)_{\mathrm{Y}}$ compounds at various sintering temperatures. 
Table 2 Chemical analysis data of typical specimens.

\begin{tabular}{|c|c|c|}
\hline Composition & Chemical analysis & $\mathrm{n}_{\mathrm{B}}$ \\
\hline $\mathrm{BaO} \cdot 2 \mathrm{ZnO} \cdot 8 \mathrm{Fe}_{2} \mathrm{O}_{3}$ & 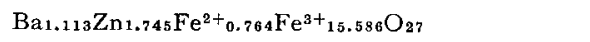 & 32.4 \\
\hline $\begin{aligned}\left\{(\mathrm{BaO})_{0.091}(\mathrm{ZnO})_{0.182}\left(\mathrm{Fe}_{2} \mathrm{O}_{3}\right)_{0.723}\right\}_{94} & \left(\mathrm{Al}_{2} \mathrm{O}_{3}\right)_{4}\left(\mathrm{La}_{2} \mathrm{O}_{3}\right)_{2}\end{aligned}$ & 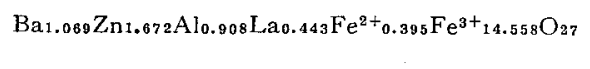 & 32.9 \\
\hline
\end{tabular}

に Ba-Zn 系及び Ba-Zn-Al-La 系化合物の混合組成之 化学分析值を示すか，1 分子当たりの磁気モーメント $\mathrm{n}_{\mathrm{B}}$ につては, $32.4 \mu_{B}$ 及び $32.9 \mu_{B}$ がそれぞれ得られ ており, $n_{B}$ につてはほぽ同等あるいい若干 $\mathrm{Al}, \mathrm{La}$ 置 換によって大きな值を示している，さらに，置換した金 属イオン $\left(\mathrm{Al}^{+++}, \mathrm{La}^{+++}\right)$の結晶内位置については, $\mathrm{Al}^{+++}$はスピン方向が上向きの $\mathrm{Fe}^{+++}$位置であるとの報 告8,15)があり, $\mathrm{Al}^{+++}$は $n_{B}$ を減少させるあのと考允られ る. $\mathrm{La}^{+++}$については, その置換位置に関しては明確な 結諭が得られていない. しかし， $\mathrm{Al}^{+++}$によって減少し た $n_{B}$ を上昇させている点，さらに化学分析值加の金 属イオン此等を考虑すると, $\mathrm{La}^{+++}$はスピン方向下向き の位置江置換する向のと考えられる。すなわち $\mathrm{Zn}^{++}$之 同梯の働きであると思われる。一方，置換位置の考察之 は別に Ba-Zn-Al-La 系化合物における 2 価イオンと 3 価イオンのモル比は3.1:15.9と, 化学量的な值(3:16)に 近いことは注目すべきととである。

Fig. 7 は，前述の磁気特性で最高の磁気特性が得られ た $\left\{(\mathrm{BaO})_{0.091}(\mathrm{ZnO})_{0.182}\left(\mathrm{Fe}_{2} \mathrm{O}_{3}\right)_{0.727}\right\}_{94}\left(\mathrm{Al}_{2} \mathrm{O}_{3}\right)_{4}\left(\mathrm{La}_{2} \mathrm{O}_{3}\right)_{2}$

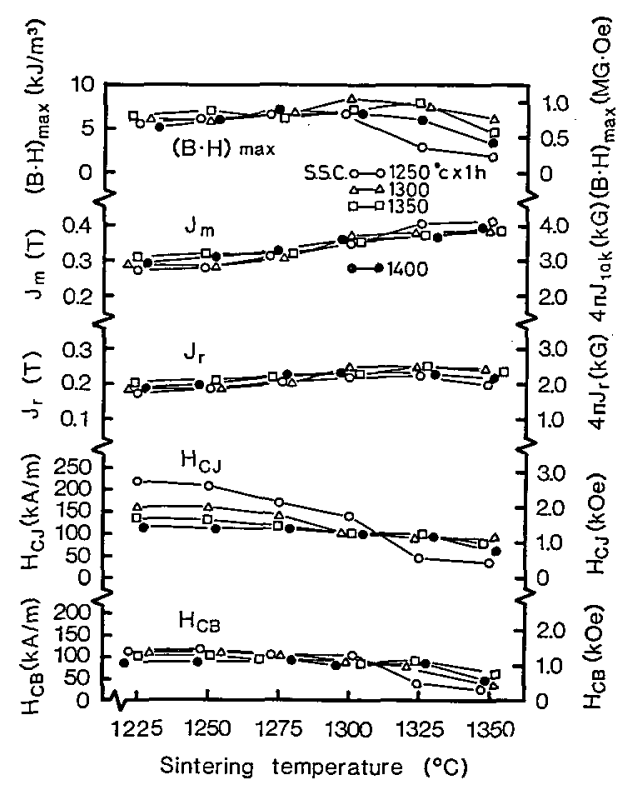

Fig. 7 Effect of sintering temperature on magnetic properties of $\left\{(\mathrm{BaO})_{0.091}(\mathrm{ZnO})_{0.182}\left(\mathrm{Fe}_{2} \mathrm{O}_{3}\right)_{0.727}\right\}_{94}$ $\left(\mathrm{Al}_{2} \mathrm{O}_{3}\right)_{4}\left(\mathrm{La}_{2} \mathrm{O}_{3}\right)_{2}$ compound at various semisintering temperatures.
化合物の本焼成温度と磁気特性の関係について示したも のである. この時の仮焼成温度は $1250 \sim 1400^{\circ} \mathrm{C}$ まで 変化させた。四から知られるように, $\mathrm{J}_{\mathrm{m}}$ については本 燒成温度の上昇とともに增加を示し， $\mathrm{J}_{\mathbf{r}}$ は本焼成温度 $1225 \sim 1300^{\circ} \mathrm{C}$ の温度範囲优拉い上昇, その後は一定

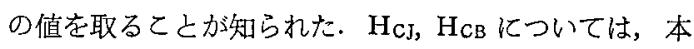
烊成温度の上异とともに減少することが知られた。 $(\mathrm{BH})_{\max }$ は，本烓成温度の上昇とともに增加を示し，本 焼成温度 $1300 \sim 1325^{\circ} \mathrm{C}$ 付近にて, 最大值を示すととが 知られた。

また, この化合物の仮焼成温度に対する磁気特性の影 響については，あまり大きな変化は見られないが，仅烤 成温度 $1250^{\circ} \mathrm{C}$ で作製した試料については本烓成温度の 上昇に伴う保磁力の減少が, 他の仮烧成温度の試料に比 較して大きいことが知られた. 以上， $\mathrm{X}=4, \mathrm{Y}=2$ 組成化 合物においては，仮㜔成温度 $1300^{\circ} \mathrm{C}$, 本焼成温度 $1300^{\circ} \mathrm{C}$ で, $\mathrm{J}_{\mathrm{m}}=0.373 \mathrm{~T}, \mathrm{~J}_{\mathrm{r}}=0.250 \mathrm{~T}, \mathrm{H}_{\mathrm{CJ}}=104.8 \mathrm{kA} / \mathrm{m}$, $\mathrm{H}_{\mathrm{CB}}=90.4 \mathrm{kA} / \mathrm{m},(\mathrm{BH})_{\max }=8.42 \mathrm{~kJ} / \mathrm{m}^{3}$ の最高值が得 られ，従来の等方性M型 $\mathrm{Ba}, \mathrm{Sr}$ フェライト磁石とほほ 同等の磁石特性を有することが知られた.

また，本実験で最高の $(\mathrm{BH})_{\max }=8.42 \mathrm{~kJ} / \mathrm{m}^{3}$ が得ら れた試料についての $\mathrm{J}_{\mathrm{r}}=0.250 \mathrm{~T}$ は, 同一組成, 同一作 製条件に上る異方性磁石の $\mathrm{J}_{\mathrm{r}}=0.405 \mathrm{~T}^{11}$ の $1 / 2$ 以上て あったため, 試料を直方体に切り出し,プレス方向に平行 方向と重直方向の磁気特性をそれぞれ測定した (Fig. 8). その結果, 図から明らかなように試料仙異方性がつい ているととが認められる．とのように，Ba-Zn-Al-La

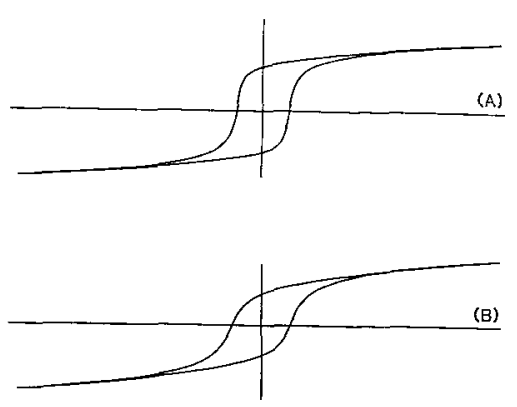

Fig. 8 Magnetic hysteresis curves of $\left\{(\mathrm{BaO})_{0.091}\right.$ $\left.(\mathrm{ZnO})_{0.182}\left(\mathrm{Fe}_{2} \mathrm{O}_{3}\right)_{0.727}\right\}_{84}\left(\mathrm{Al}_{2} \mathrm{O}_{3}\right)_{4}\left(\mathrm{La}_{2} \mathrm{O}_{3}\right)_{2}$ compound.

(A) parallel to the pressing direction.

(B) perpendicular to the pressing direction. 


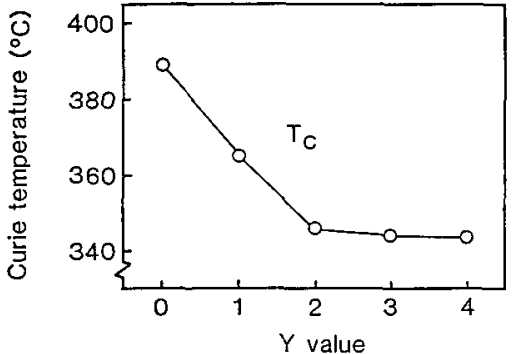

Fig. 9 Curie temperature of $\left\{(\mathrm{BaO})_{0.091}(\mathrm{ZnO})_{0.182}\right.$ $\left.\left(\mathrm{Fe}_{2} \mathrm{O}_{3}\right)_{0.727}\right\}_{96-\mathrm{Y}}\left(\mathrm{Al}_{2} \mathrm{O}_{3}\right)_{4}\left(\mathrm{La}_{2} \mathrm{O}_{3}\right)_{\mathrm{Y}}$ compo* unds.

S.S.C.: $1300^{\circ} \mathrm{C} \times 1$ h, S.C.: $1300^{\circ} \mathrm{C} \times 0.5 \mathrm{~h}$
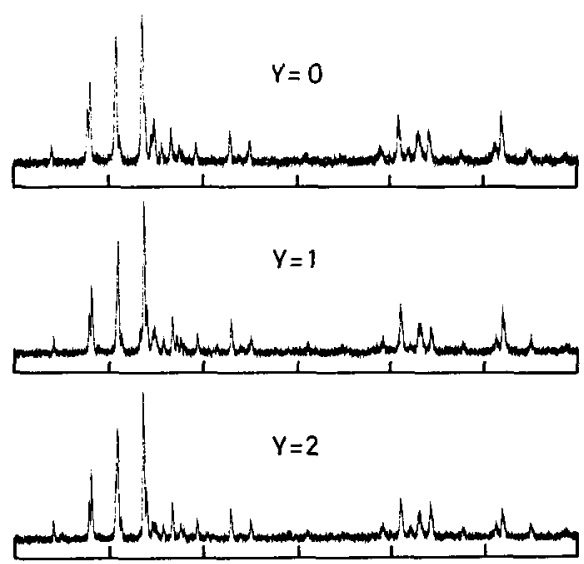

$\mathrm{Y}=3$
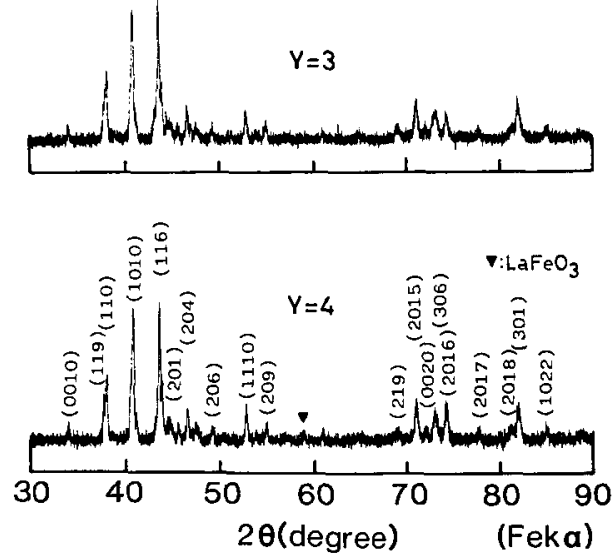

Fig. $10 \mathrm{X}$-ray diffraction patterns of $\left\{(\mathrm{BaO})_{0.091_{1}(\mathrm{ZnO})_{0.182}}\right.$ $\left.\left(\mathrm{Fe}_{2} \mathrm{O}_{3}\right)_{0.727}\right\}_{96}-\mathrm{Y}\left(\mathrm{Al}_{2} \mathrm{O}_{3}\right)_{4}\left(\mathrm{La}_{2} \mathrm{O}_{3}\right)_{\mathrm{Y}}$ compounds.

系W型フェライト磁石材料は，M型フェライトと同様に 若干の機械的な方向性がつくととを示唆している.

Fig. 9 は, $\left\{(\mathrm{BaO})_{0.091}(\mathrm{ZnO})_{0.182}\left(\mathrm{Fe}_{2} \mathrm{O}_{3}\right)_{0.727}\right\}_{96-\mathrm{Y}}\left(\mathrm{Al}_{2}\right.$ $\left.\mathrm{O}_{3}\right)_{4}\left(\mathrm{La}_{2} \mathrm{O}_{3}\right)_{\mathrm{Y}}$ 化合物伒いて, Y を0 4 たときのキュリー温度 $\mathrm{T}$ c を示したむのである。乙の時 作製条件枯, S.S.C. $1300^{\circ} \mathrm{C} \times 1 \mathrm{~h}$, S. C. $1300^{\circ} \mathrm{C} \times$ $0.5 \mathrm{~h}$ である. $\mathrm{T}_{\mathrm{c}}$ は， $\mathrm{Y}=0$ 〜2 の範围で直線的な減少を 示し，その後ほぼ一定の值を取ることが知られた。また，
最高の磁気特性が得られた $\mathrm{X}=4, \mathrm{Y}=2$ 組成では, $\mathrm{T}_{\mathrm{C}}=$ $346^{\circ} \mathrm{C}$ であった.

3-2-2 X線回折, 格子定数, 組織, 他

Fig. 10 は, $\left\{(\mathrm{BaO})_{0.091}(\mathrm{ZnO})_{0.182}\left(\mathrm{Fe}_{2} \mathrm{O}_{3}\right)_{0.727}\right\}_{96-\mathrm{Y}}\left(\mathrm{Al}_{2}\right.$ $\left.\mathrm{O}_{3}\right)_{4}\left(\mathrm{La}_{2} \mathrm{O}_{3}\right)_{\mathrm{Y}}$ 化合物に沶いて，Y=0〜4 のそれぞれの組 成でのX線回折図形であり，仮烧成温度，本烓成温度い ずれあ $1300^{\circ} \mathrm{C}$ で作製した粉末のものである. $\mathrm{Y}=0 \sim 3$ の組成ではW相単相を示しているが, $\mathrm{La}_{2} \mathrm{O}_{3}$ 置換量の最 む多い $\mathrm{Y}=4$ 組成においては，W相の他にわずかながら $\mathrm{LaFeO}_{3}$ 化合物からの反射が見られ，乙の $\mathrm{Y}=4$ の組成 ではW相単相とはならないととが知られた。

Fig. 11 は, $\left\{(\mathrm{BaO})_{0.091}(\mathrm{ZnO})_{0.182}\left(\mathrm{Fe}_{2} \mathrm{O}_{3}\right)_{0.727}\right\}_{96-\mathrm{Y}}\left(\mathrm{Al}_{2}\right.$ $\left.\mathrm{O}_{3}\right)_{4}\left(\mathrm{La}_{2} \mathrm{O}_{3}\right)_{\mathrm{Y}}$ 化合物倸括いて, Y の変化に対する格子 定数 (a 及び c) 走したあのである. 図加ら知られるよ うに，格子定数 a については，Y の值とは無関係に活ば 一定の值を示すが，格子定数 $\mathrm{c}$ に関しては， $\mathrm{Y}=0 \sim 3$ の 範囲で直線的な減少を示し，その後は一定の值を取って いる. そして, 最高の磁気特性を示した $\mathrm{X}=4, \mathrm{Y}=2$ の 組成に扮いて $\mathrm{a}=5.883 \times 10^{-10} \mathrm{~m}, \mathrm{c}=32.84 \times 10^{-10} \mathrm{~m}$ 力゙得 られた.このような格子定数の変化及ご前述のキュリー 温度, $\mathrm{X}$ 線回折図形の $\mathrm{La}_{2} \mathrm{O}_{3}$ 㯰換量に対する変化の様 子から，乙の組成におりる $\mathrm{La}_{2} \mathrm{O}_{3}$ の固溶限は，およそ $\mathrm{Y}=2$ 2 3 であると考えられる。

Fig. 12 は, Fig. 9, 10, 11 之同㥞の組成に标ける密度 $\mathrm{D}$ 上收縮率 $\mathrm{S}$ を示したものである. 収縮率は $\mathrm{Y}=0$ に おいて $5.8 \%$ 取り， $\mathrm{Y}$ の增加とと屯に上昇して $\mathrm{Y}=3$ の組成で11.196を示すことが知られた。さらに $\mathrm{Y}=4$ の 組成に至っては $\mathrm{Y}=3$ の場合とほぼ同じ值である。密度 については $\mathrm{Y}=0$ 0 4 の範囲において一様に增加する傾 向が認められた。なお，磁気特性が良好であった $\mathrm{X}=4$ ， $\mathrm{Y}=2$ の組成では, $\mathrm{s}=9.8 \%, \mathrm{D}=4.68 \mathrm{Mg} / \mathrm{m}^{3}$ が得られ t.

Photo. 1 は, 最高の磁気特性が得られた, $\left\{(\mathrm{BaO})_{0.091}\right.$ $\left.(\mathrm{ZnO})_{0.182}\left(\mathrm{Fe}_{2} \mathrm{O}_{3}\right)_{0.727}\right\}_{94}\left(\mathrm{Al}_{2} \mathrm{O}_{3}\right)_{4}\left(\mathrm{La}_{2} \mathrm{O}_{3}\right)_{2}$ 化合物の S.E. M. 比よる組織写真である。本燒成温度は $1250 \sim 1350^{\circ} \mathrm{C}$

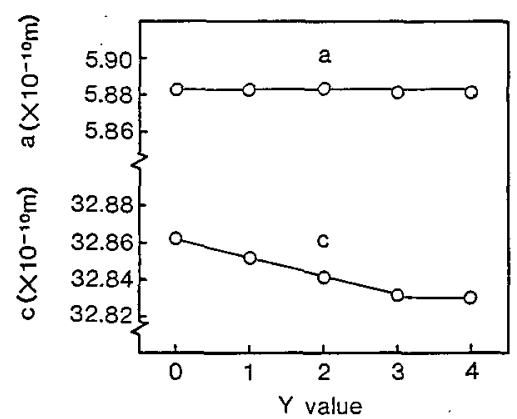

Fig. 11 Lattice constant of $\left\{(\mathrm{BaO})_{0.001}(\mathrm{ZnO})_{0.182}\right.$ $\left.\left(\mathrm{Fe}_{2} \mathrm{O}_{3}\right)_{0.727}\right\}_{96-\mathrm{Y}}\left(\mathrm{Al}_{2} \mathrm{O}_{3}\right)_{4}\left(\mathrm{La}_{2} \mathrm{O}_{3}\right)_{\mathrm{Y}}$ compounds.

S.S.C.: $1300^{\circ} \mathrm{C} \times 1$ h, S.C.: $1300^{\circ} \mathrm{C} \times 0.5 \mathrm{~h}$ 


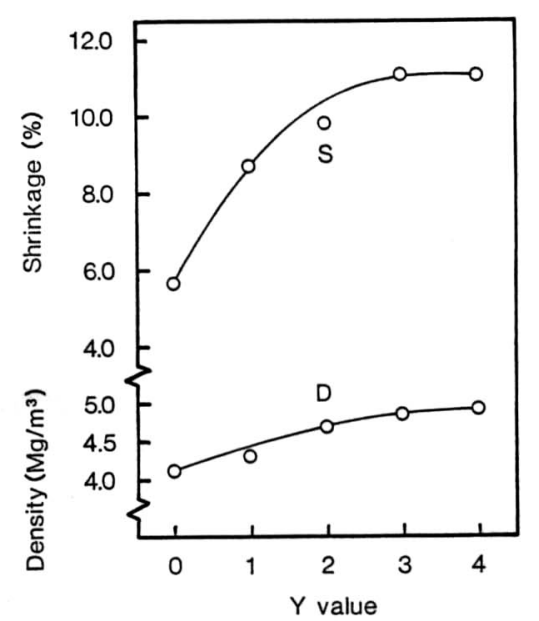

Fig. 12 Sintered density and shrinkage of $\left\{(\mathrm{BaO})_{0.091}\right.$ $\left.(\mathrm{ZnO})_{0.182}\left(\mathrm{Fe}_{2} \mathrm{O}_{3}\right)_{0.72}\right\}_{96-\mathrm{Y}}\left(\mathrm{Al}_{2} \mathrm{O}_{3}\right)_{4}\left(\mathrm{La}_{2} \mathrm{O}_{3}\right)_{\mathrm{Y}}$ compounds.

S.S.C.: $1300^{\circ} \mathrm{C} \times 1 \mathrm{~h}$, S.C.: $1300^{\circ} \mathrm{C} \times 0.5 \mathrm{~h}$
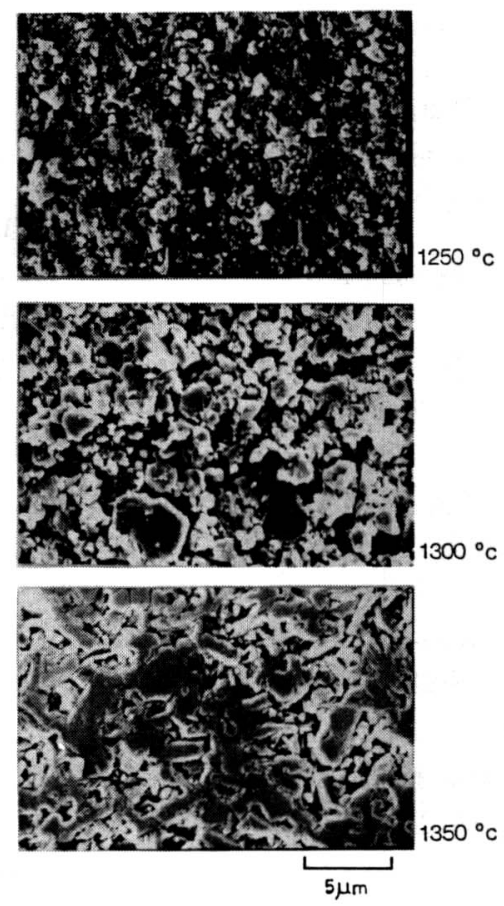

Photo. 1 Electron-micrographs of $\left\{(\mathrm{BaO})_{0.091}(\mathrm{ZnO})_{0.182}\right.$ $\left.\left(\mathrm{Fe}_{2} \mathrm{O}_{3}\right)_{0.727}\right\}_{94}\left(\mathrm{Al}_{2} \mathrm{O}_{3}\right)_{4}\left(\mathrm{La}_{3} \mathrm{O}_{3}\right)_{2}$ compound sintered at various temperatures.

であり，それぞれプレス方向に対して垂直方向のあのを 示した. 写真から知られるように，本狫成温度が上昇す るにつれて粒子が成長している様子が観察され，本焼成 温度 $1300^{\circ} \mathrm{C}$ の試料の粒径は $1 \sim 4 \mu \mathrm{m}$ 程度であった. ま た，いずれの組織からも六角板状組織が観察され，前述 の機械的方向性が若干ついていることが確認された.

\section{IV 結 言}

以上, 等方性 Ba-Zn-Al-La 系W型フェライト磁石に ついて, 複雑な雾囲気制御なしに, 一般のフェライト磁 石の作製法を用いて種々実験検討した結果を要約すると 次のようである.

(1)Ba-Zn 系化合物においての磁石特性としては, $(\mathrm{BH})_{\max }=5.00 \mathrm{~kJ} / \mathrm{m}^{3}$ が最高の值であり, 一般の等方 性M型磁石と比較して劣ることが知られた.

(2) $\mathrm{Al}_{2} \mathrm{O}_{3}$ は, $\mathrm{Ba}-\mathrm{Zn}$ 系化合物に固溶し, 磁石特性を向上 させることが知られた. 特に X=1において, その効 果は大きい.

(3)Ba-Zn-Al-La 系化合物は, $\mathrm{X}=4, \mathrm{Y}=1 \sim 2$ の組成に おいて $(B H)_{\max }=8.00 \sim 8.42 \mathrm{~kJ} / \mathrm{m}^{3}$ を示し, 等方性 M型 $\mathrm{Ba}, \mathrm{Sr}$ フェライト磁石とほぼ同等の磁石特性を 有することが知られた.

(4) Ba-Zn-Al-La系W型フェライト磁石材料は, M型フェ ライトと同様に機械的方向性がつき易いととが知られ た.

(5)等方性 $\mathrm{Ba}-\mathrm{Zn}-\mathrm{Al}-\mathrm{La}$ 系W型フェライト磁石で, 本実 験にて得られた最高の磁石特性の作製条件並びに諸特 性は以下のようである. 組成: $\left\{(\mathrm{BaO})_{0.091}(\mathrm{ZnO})_{0.182}\right.$ $\left.\left(\mathrm{Fe}_{2} \mathrm{O}_{3}\right)_{0.727}\right\}_{94}\left(\mathrm{Al}_{2} \mathrm{O}_{3}\right)_{4}\left(\mathrm{La}_{2} \mathrm{O}_{3}\right)_{2}$

作製条件 : S. S.C. $1300^{\circ} \mathrm{C} \times 1 \mathrm{~h}$ in air S. C. $1300^{\circ} \mathrm{C} \times 0.5 \mathrm{~h}$ in air 諸特 性: $\mathrm{J}_{\mathrm{m}}=0.373 \mathrm{~T}, \mathrm{~J}_{\mathrm{r}}=0.250 \mathrm{~T}$,

$$
\begin{aligned}
& \mathrm{H}_{\mathrm{CJ}}=104.8 \mathrm{kA} / \mathrm{m}, \quad \mathrm{H}_{\mathrm{CB}}=90.4 \mathrm{kA} / \mathrm{m}, \\
& (\mathrm{BH})_{\max }=8.42 \mathrm{~kJ} / \mathrm{m}^{3}, \mathrm{~T}_{\mathrm{C}}=346^{\circ} \mathrm{C}, \\
& \mathrm{D}=4.68 \mathrm{Mg} / \mathrm{m}^{3}, \quad \mathrm{a}=5.883 \times 10^{-10} \mathrm{~m}, \\
& \mathrm{c}=32.84 \times 10^{-10} \mathrm{~m}, \quad \mathrm{c} / \mathrm{a}=5.582 .
\end{aligned}
$$

\section{文献}

1) F. K. Lotgering, P. H. G. M. Vormans and M.AH. Huyberts: J. Appl. Phys., 51 (1980), 5913.

2) G. Albanese and G. Asti: IEEE Trans. Magn., MAG-6 (1970), 158.

3) T. Besagni, A. Deriu, F. Licci, L. Pareti and S. Rinaldi: IEEE Trans. Magn., MAG-17 (1981), 2636.

4) F. Licci, L. Pareti and S. Rinaldi: J. Appl. Phys., 52 (1981), 2526.

5) T. Besagni, A. Deriu, F. Licci and S. Rinaldi: J. Magn. and Magn. Mater., 31-34 (1983), 791.

6) H. Kojima, C. Miyakawa, T. Sato and K. Goto: Japan. J. Appl. Phys., 24 (1985), 51.

7) L. G. Van Unitert and F. W. Swanekamp: J. Appl. Phys., 28 (1957), 482

8) G. Albanese, M. Carbucicchio, F. Bolzoni, S. Rinaldi, G. Sloccari and E. Lucchini: Physica, 86-88B (1977), 941.

9) G. Albanese, M. Carbucicchio, L. Pareti, S. Rinaldi, E. Lucchini and G. Slokar: J. Magn. and Magn. Mater., 15-18 (1980), 1453.

10) G. Albanese, M. Carbucicchio, L. Pareti and S. Rinaldi: J. Status. Solidi a, 73 (1982), K193. 
11）山元，永倉，小野，高橋：粉体粉末炲金協会昭和61年度春 季大会講演概要集, P. 144.

12）山本, 籠谷, 岡田, 本間: 日本金属学会昭和 61 年度秋期大 会一般講演概要, P. 530 .

13) H. Yamamoto, T. Kawaguchi and M. Nagakura: IEEE Trans. Magn., MAG-15 (1979), 1141.
14) H. Yamamoto and M. Nagakura: IEEE Trans. Magn., MAG-23 (1987), 294.

15) A.H. Mones and E. Banks: Phys. Chem. Solids, 4 (1958), 217.

16) F. Bertaut, A. Deschamps, R. Pauthenet and S.Pickart: J. Phys. Radium., 20 (1959), 404.
会 告

\section{昭和62年度材料科学基礎講座}

—一材料の微小部分を探る——

主 催：日本材料科学会

協 替：粉体粉末治金協会他

プログラム :

11月26日(木)表面分析を中心として

1.オージェ電子分光法 (AES)

金材技研 吉原一紘

2. 光電子分光法 (XPS) 日本鋼管 福田 安生

3. 二次イオン分析法 (SIMS-GDS)

新日鉄 大坪 孝至

4. 走查型トンネル電子顕微鏡 (STM)

東北大，森田 清三

5. 電子線マイクロアナライザー (EPMA)

島津製作所 副島 啓義

6. 総合討論

11月27日(金)バルク分析を中心として
7. X線回折
理学電機
荒木 宏侑
8. 原子吸光, ICP
金材技研
大河内春乃
9. 赤外吸収 (FTIR), ラマン分光

$\begin{array}{lrlr} & \text { 日本分光 } & \text { 池田 } & \text { 照樹 } \\ \text { 10. 核磁気共眭 (NMR) } & \text { 日本電子 } & \text { 今 } & \text { 成司 } \\ \text { 11. 電子顕微鏡 } & \text { 日立 } & \text { 永谷 } & \text { 隆 } \\ \text { 12. 総合討諭 } & & & \end{array}$

日 時：昭和 62 年11月26日(木) 27日(金)

会 場: 総評会馆 2 階

\section{千代田区神田駿河台3-2}

IEL $\quad 03(253) 1771$

（E電「お茶の水」駅下車，また垃地下鉄千代 田線「新扰茶の水」駅, 都営新宿線「小川町」

下車, B 3 出口前)

定 員：100名（定員になり次第締切ります.）

受講料：会員及び協賛学協会会員 20,000 円

$$
\text { 学生, 院生 } 5,000 \text { 円 }
$$

一 般

30,000 円

（テキスト代を含む）

申込先： $\bar{\top} 102$ 千代田区四番町8-1 的裳華房内

日本材料科学会基礎講座係

TRt $\quad 03(262) 9166$

問合先：干153目黑区中目黑2-3-12

金属材料技術研究所

喜原一紘

TEL $\quad 03(719) 2271$

申込締切：昭和62年11月20日（全）

申込方法：官製はがきに次の項目を記入して，上記の申 込先へお申迈下さい。

(1)「昭和62年度材料科学基礎講座」申込，(2) 氏名（ふりがなをつけて下さい), (3) 勤務先,

(4) 同所在地 ( $\bar{T})$, (5) 自宅住所 (T), (6) 連 絡先（自宅または勤務先いずれかを指定）及び 電話番号, (7) 申込資格（会員，協賛学協会会 員, 学生, 院生, 一般の別), (8) 受講料振込依 頼先銀行名及び振込依頼者名

払込方法 : 受講料は, 三菱銀行市厅谷支店 日本材料科学会 普通口坐 4933697 へ申込締切日までにお振込下さい，尚，受講料 は，定員締切の場合を除き，不参加の場合でむ 払い戻しいたしません。 